\title{
Parking Demand for Elementary \& Secondary Schools in Jordan
}

\author{
Bashar H. Al-Omari* and Rooa Alhamdan M \\ Department of Civil Engineering, Jordan University of Science \& Technology, Jordan
}

Submission: September 09, 2020; Published: September 17, 2020

*Corresponding author: Bashar H. Al-Omari, Department of Civil Engineering, Jordan University of Science \& Technology, Jordan

\begin{abstract}
This study aimed at investigating parking demand at elementary and secondary schools in Irbid city; the second largest city in Jordan, to identify the main influencing factors, and develop models to predict future demand based on local conditions. The major considered factors included school area, number of students, number of teachers, number of classrooms, gender of students, education level (elementary, secondary), and school ownership (public, private). A total of 118 different types of schools were surveyed from different areas in Irbid City. The required field data were collected on regular weekdays by field surveys and manual counting for the total number of parked vehicles and the variation during the schools working hours, while schools descriptive information's were obtained from the directorate of education in Irbid city. Peak demand models for different types of schools were developed using multiple linear regression analysis by SPSS software. The results of the study showed that the main affecting factors on school parking demand include the total number of students, classrooms, and teachers. However, more focus was given to the number of students due to collinearity among these main independent variables and to be consistent with the international practice.
\end{abstract}

Keywords: Parking demand, Elementary school, Secondary school, Irbid, Jordan

\section{Introduction}

Concerns are raised about traffic congestion and parking problems in Jordan as one of the developing countries with high population growth, immigration from neighbouring countries, increasing vehicle ownership and weak public transportation system, that require expansion of road networks and affect traffic operations and parking demand (both on street and off-street). Parking is an important element in the transportation system, since each driver needs to park somewhere before and after each trip. Parking has a significant effect on traffic problems like traffic congestion, traffic safety and environment. It must be effectively organized whether at on- or off-street to meet the land uses parking demand, reduce traffic problems and keep the desired levels of service for the street network.

Parking studies are main part of transportation studies used to assess the impact of new proposed developments. Findings and results represent the input needed to understand the existing parking conditions and requirements, to guide and enhance parking planning, management, and implementation of related projects. Parking studies may also help to set possible improvements required for handling existing traffic conditions and accommodating future changes to create balance between parking supply and demand especially in cities where the cost of land is expensive. It is necessary to estimate parking demand requirements at existing and proposed developments to assess parking adequacy and their impact on the transportation network. Parking demand models are necessary tools to guide engineers, planners, and decision makers in transportation planning and parking management.

It is not accurate to use international parking demand models in Jordan to estimate or predict the required parking demand without validation for local conditions since there are different socioeconomic and traffic characteristics between different countries, especially between developed and undeveloped ones. So it is essential to develop parking demand models based on local traffic and socioeconomic conditions in order to provide more accurate estimates. This study aims at investigating the required parking demand at elementary and secondary schools in Irbid city, identify affecting factors, and develop models to predict future parking demand as a function of the main influencing factors such as the school area, number of class rooms, number of students, number of teachers, gender of students, school ownership (public, private), etc. Parking demand models are used 
to provide prediction for future parking demand at developments for planning and management and creating balance between demand and supply.

\section{Literature Review}

The Institute of Transportation Engineers [1] has defined parking generation as "an educational tool for planners, transportation professionals, zoning boards and others who are interested in estimating parking demand of proposed development". It has also defined parking supply as "the total number of parking spaces that are built or available at the study site, regardless of whether or not are utilized" and parking demand as "the total number of parking spaces required at a given site during the peak period". It has been found by different international studies that the total number of students is the main variable that is positively related and significantly affect the number of parking spaces needed at school's land use. Other variables that may affect schools parking demand include number of teachers, number of classrooms and school area. ITE [1] predicts parking demand rates for different types of schools (elementary, middle, high, private, and schools for blind) at different location types based on the number of students and presents linear relationships between school peak parking demand and the number of students.

Dubai Municipality [2] has a parking generation manual which estimates the required parking rates for different school levels based on the number of students. Different factors are presented based on school level (kindergarten, elementary and intermediate, and secondary), ownership (private, government), period (school morning peak, school afternoon peak, traffic peak hour), and gender (male, female). Riyadh Municipality [3] has a Parking Generation Manual which estimates parking rates for elementary governmental schools in Riyadh city based on the total area of the school, number of classes, number of students, and number of employees. Different studies were conducted in Jordan at different land uses to investigate parking demand and develop models for parking demand prediction based on local conditions. Al-Masaeid et al. [4] have conducted a study in Jordan to estimate parking generation rates at different land uses including apartment buildings, restaurants, shopping centers, office buildings, hospitals, and hotels and found lower parking demand rates as compared with developing countries. Ghuzlan et al. [5] have investigated the parking demand for multistory apartment buildings in Jordan, and identified their significant influencing factors which included building age (years), number of floors, apartment gross floor area $\left(\mathrm{m}^{2}\right)$, average apartment income (JD), average apartment car ownership, and location of the building.

A study at the University of Washington [6] has conducted parking field surveys at a high school located at Seattle metropolitan area and collected data about location, site area, building area, time of regular classes, total number of students, teachers, and administrators and developed models for parking rate as a function of the number of students. Wong et al. [7] conducted a parking demand study in Hong Kong at different land uses to investigate parking demand for both private cars and goods vehicles. Linear parking demand models were developed for different land uses including schools. A study at the Arizona state university [8] has surveyed parking demand at three elementary schools in Maricopa county region in Arizona with data on the number of students, number of employees, and school size. Parking demand rate was calculated as a function of the number of students, resulting in a rate of 25 vehicle/student as compared to 14 vehicle/student in the national ITE parking generation manual.

\section{Data Collecion and Reduction}

The study data were collected from Irbid city which is the second largest city in Jordan after the capital (Amman), with a population of 929,224 [9]. The city is in the northern part of Jordan with most of its total area classified as residential. The directorate of education in Irbid was contacted to obtain the available information about schools including school area, education type, education level, students' gender, number of students, number of classrooms, and number of teachers. Field surveys and manual counting was performed for collecting parking data during schoolworking hours. The study included 118 elementary and secondary schools from Irbid city to investigate their parking demand and the main influeing factos [10]. different types of schools were considered and surveyed in the study including public and private schools for male, female, and mixed students, in elementary and secondary levels. (Table 1) presents a list of abbreviations for the main dependent and independent variables as they are used in this study.

Parking demand data were collected through field surveys to obtain accurate information about existing parking supply and the peak number of parked vehicles at each school site with parking demand variation along the schoolworking hours. Vehicle counts at schools were conducted as follows:

a. The total number of parked vehicles were continuously counted by visual observation and recorded manually on a regular weekday.

b. Vehicles that were considered in the schools parking demand surveys included personal automobiles for teachers and administrative staff, school buses, commercial vehicles for school needs, and vehicles for school visitors such as students' parents and education supervisors, and for special related activities.

c. To get the accurate data for real peak demand, all access points (gates) to the schools were considered in this study.

d. Some teachers, and administrative staff preferred to park a little far from the schools buildings or at adjacent streets to avoid congestion in front of the schools gates and these vehicles were also considered. 


\section{Civil Engineering Research Journal}

e. During field surveys, the counting was only for the parked vehicles for school purposes and not for any other developments activities.

Some descriptive independent variables were coded as $(0$, $1)$ or $(0,1,2)$ for regression analysis and model development as shown in (Table 2). (Table 3) shows a sample of the collected data that were surveyed which includes descriptive information and peak parking demand for secondary private schools (all are mixed and morning schools). Similar data were collected for all school types.

Table 1: Abbreviations for main dependent and independent variables.

\begin{tabular}{|c|c|}
\hline Variable & Abbreviation \\
\hline Number of peak parked vehicles & PV \\
\hline Total area of the school $\left(\mathrm{m}^{2}\right)$ & $\mathrm{A}$ \\
\hline Number of classrooms in the school & NC \\
\hline Number of students in the school & NS \\
\hline Number of teachers in the school & NT \\
\hline
\end{tabular}

Table 2: Coding of the descriptive independent variables.

\begin{tabular}{|c|c|c|}
\hline Variable & Code & Meaning \\
\hline School ownership & 0 & Private school \\
\hline & 1 & Public school \\
\hline Students gender & 0 & Female \\
\hline & 1 & Mixed \\
\hline Education Level & 2 & Elementary \\
\hline & 0 & Secondary \\
\hline Education type & 1 & Academic \\
\hline & 0 & Professional \\
\hline School time & 1 & Morning \\
\hline & 0 & Afternoon \\
\hline
\end{tabular}

Table 3: Sample of collected data for secondary private schools

\begin{tabular}{|c|c|c|c|c|c|}
\hline Name & Area $\mathbf{( m}^{\mathbf{2}} \mathbf{)}$ & NS & NC & NT & PV \\
\hline Rosary Sisters & 6349 & 814 & 31 & 19 & 26 \\
\hline Roman Catholic & 4181 & 440 & 54 & 72 & 36 \\
\hline Irbid Model & 2346 & 1660 & 41 & 56 & 31 \\
\hline Al-Jeel Al-Jadeed & 3884 & 1127 & 31 & 37 & 22 \\
\hline Al-Nahda Al-Ahleya & 2642 & 675 & 33 & 45 & 21 \\
\hline Dar Al-Oloom & 7329 & 603 & & & 36 \\
\hline
\end{tabular}

\section{Analysis and Modeling}

Correlation matrices were developed for each school type to investigate correlation between different variables and parking demand before model development. (Table 4) presents a sample correlation matrix for male elementary public schools.

It can be seen from the above table, that parking demand is highly correlated with the number of students, number of classrooms, and number of teachers which are also highly correlated with each other's. The same trend was also noticed for other types of schools. The statistical analysis linear regression method was performed on the collected data using the statistical package for social sciences (SPSS) software in order to develop models for predicting school peak parking demand as a function of its influencing variables. The highest number of parked vehicles during observation period was the value considered in regression analysis and model development. (Table 5) through 11 present the developed models for parking rate as functions of the main affecting variables. All equations and parameters are significant at 95\% confidence level, where: Since NT, NC, and NS have high collinearity with each other and to be consistent with the international practice, it has been decided to focus 


\section{Civil Engineering Research Journal}

on the total number of students (NS) in the developed parking demand models. (Tables 6-11) (Table 12) presents a summary of the developed models for the school peak parking demand as a function of the number of students for different school types. (Figure 1) shows the relationship between parking demand and the number of students at all school types combined. The model $\mathrm{R} 2$ is weak (0.40), so it is not recommended to use a combined model and it is preferred to use separate models (rates) for different school types.

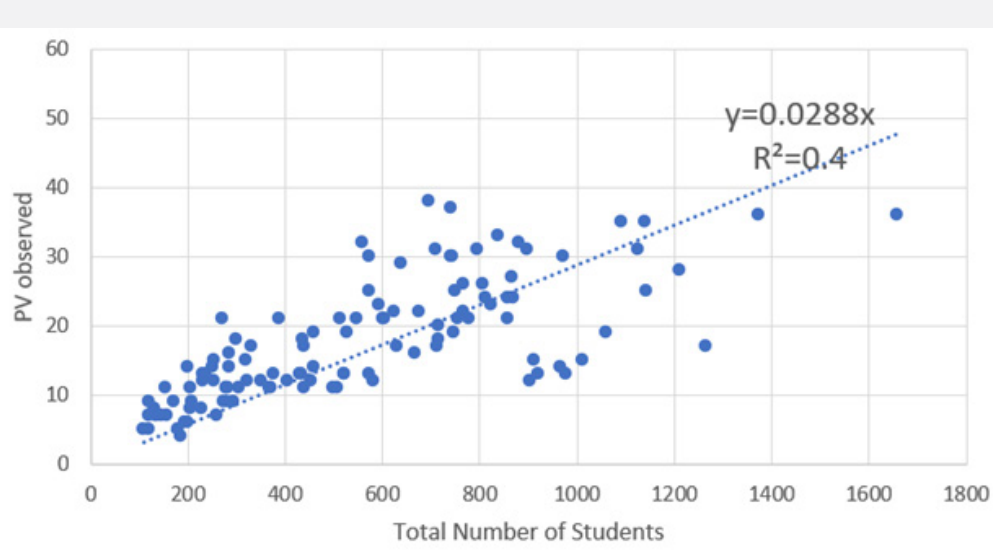

Figure 1: The relationship between parking demand and number of students at all school types combined.

Table 4: Correlation matrix for male elementary public schools.

\begin{tabular}{|c|c|c|c|c|c|}
\hline Variable & PV & A & NS & NC & NT \\
\hline PV & 1 & & & & \\
\hline A & 0.1981 & 1 & 1 & & \\
\hline NS & 0.9138 & 0.0645 & 0.8942 & 1 & 0.9375 \\
\hline NC & 0.9068 & 0.0695 & 0.8189 & 1 \\
\hline NT & 0.9045 & 0.1646 & & \\
\hline
\end{tabular}

Table 5: Developed models for male elementary public schools.

\begin{tabular}{|c|c|c|c|}
\hline Variable & Parking Demand & $\mathbf{R}^{2}$ adj & F-value \\
\hline Number of students & $0.035(\mathrm{NS})$ & 0.98 & 952 \\
\hline Number of teachers & $0.724(\mathrm{NC})$ & 0.96 & 499 \\
\hline Number of classrooms & $1.211(\mathrm{NT})$ & 0.97 & 711 \\
\hline
\end{tabular}

NS = number of students in the school.

NT = number of teachers in the school.

$\mathrm{NC}=$ number of classrooms in the school.

Table 6: Developed models for male secondary public schools.

\begin{tabular}{|c|c|c|c|}
\hline Variable & Parking Demand & $\mathbf{R}^{2}$ adj & F-value \\
\hline Number of students & $0.041(\mathrm{NS})$ & 0.94 & 263 \\
\hline Number of teachers & $0.724(\mathrm{NT})$ & 0.98 & 767 \\
\hline Number of classrooms & $1.328(\mathrm{NC})$ & 0.96 & 401 \\
\hline
\end{tabular}

Table 7: Developed models for female elementary public schools.

\begin{tabular}{|c|c|c|c|}
\hline Variable & Parking Demand & $\mathbf{R}^{2}$ adj & F-value \\
\hline Number of students & $0.071(\mathrm{NS})$ & 0.89 & 162 \\
\hline Number of teachers & $0.376(\mathrm{NT})$ & 0.94 & 284 \\
\hline Number of classrooms & $0.622(\mathrm{NC})$ & 0.93 & 252 \\
\hline
\end{tabular}




\section{Civil Engineering Research Journal}

Table 8: Developed models for female secondary public schools.

\begin{tabular}{|c|c|c|c|}
\hline Variable & Parking Demand & $\mathbf{R}^{2}$ adj & F-value \\
\hline Number of students & $0.027(\mathrm{NS})$ & 0.94 & 226 \\
\hline Number of teachers & $0.452(\mathrm{NT})$ & 0.99 & 273 \\
\hline Number of classrooms & $0.914(\mathrm{NC})$ & 0.97 & 447 \\
\hline
\end{tabular}

Table 9: Developed models for mixed elementary public schools.

\begin{tabular}{|c|c|c|c|}
\hline Variable & Parking Demand & $\mathbf{R}^{\mathbf{2}}$ adj & F-value \\
\hline Number of students & $0.026(\mathrm{NS})$ & 0.97 & 308 \\
\hline Number of teachers & $0.610(\mathrm{NT})$ & 0.98 & 431 \\
\hline Number of classrooms & $0.500(\mathrm{NC})$ & 0.99 & 613 \\
\hline
\end{tabular}

Table 10: Developed models for mixed elementary private schools.

\begin{tabular}{|c|c|c|c|}
\hline Variable & Parking Demand & $\mathbf{R}^{2}$ adj & F-value \\
\hline Number of students & $0.035(\mathrm{NS})$ & 0.92 & 359 \\
\hline Number of teachers & $0.680(\mathrm{NT})$ & 0.92 & 398 \\
\hline Number of classrooms & $0.883(\mathrm{NC})$ & 0.93 & 451 \\
\hline
\end{tabular}

Table 11: Developed models for mixed secondary private schools.

\begin{tabular}{|c|c|c|c|}
\hline Variable & Parking Demand & R $^{\mathbf{a} \text { adj }}$ & F-value \\
\hline Number of students & $0.026(\mathrm{NS})$ & 0.96 & 139 \\
\hline Number of teachers & $0.523(\mathrm{NT})$ & 0.99 & 629 \\
\hline Number of classrooms & $0.710(\mathrm{NC})$ & 0.99 & 643 \\
\hline
\end{tabular}

Table 12: Summary of peak school parking demand models.

\begin{tabular}{|c|c|}
\hline School Type & Parking Demand \\
\hline Elementary public (male) & 0.035 (NS)* \\
\hline Secondary public (male) & 0.041 (NS) \\
\hline Elementary public (female) & 0.071 (NS) \\
\hline Secondary public (female) & 0.027 (NS) \\
\hline Elementary public (mixed) & 0.026 (NS) \\
\hline Elementary private (mixed) & 0.035 (NS) \\
\hline Secondary private (mixed) & 0.026 (NS) \\
\hline
\end{tabular}

${ }^{*}$ NS: number of students in the school.

\section{Comparison with Other Models}

(Figure 2) shows an example of a comparison for parking demand based on the observed data and developed models with the corresponding predicted values from ITE and Dubai manuals for male elementary public schools. As can be seen from the above figure, the developed rates provide closer estimates for parking demand while international models provide high overestimates as compared to the field observations.

\section{Conclusion \& Recommendations}

Empirical models were developed for predicting peak parking demand at each type of school as a function of the main influencing variables. Key conclusions are summarized as follows:
I. Depending on data collection and analysis it was found that the main affecting factors on school parking demand include the total number of students, classrooms, and teachers. However, more focus was given to the number of students due to high collinearity between the three factors and to be consistent with the international practice.

II. The relationships between the dependent variable (peak school parking demand) and the affecting factors have liner forms.

III. A weak relationship was found between average peak parked vehicles and the total number of students for all school types combined, so it is not recommended to use a combined model and it is preferred to use separate models/rates for different school types. 


\section{Civil Engineering Research Journal}

IV. The developed school parking demand rates provide closer estimates than commonly used international models as compared to field observations.

Based on the data collection, analysis, and model developments in this research, it is recommended to:

1. Conduct similar studies at different land uses to establish a comprehensive parking demand manual based on local conditions instead of using foreign manuals with different socioeconomic and traffic characteristics.

2. Utilize the results of this study in planning, design, construction, and study of school parking in Jordan.

3. Validate the study results for other cities in the country.

Conduct similar studies every few years to find out the effects of changes over time in socioeconomic characteristics, population, vehicle ownership, to propose possible updates if required.

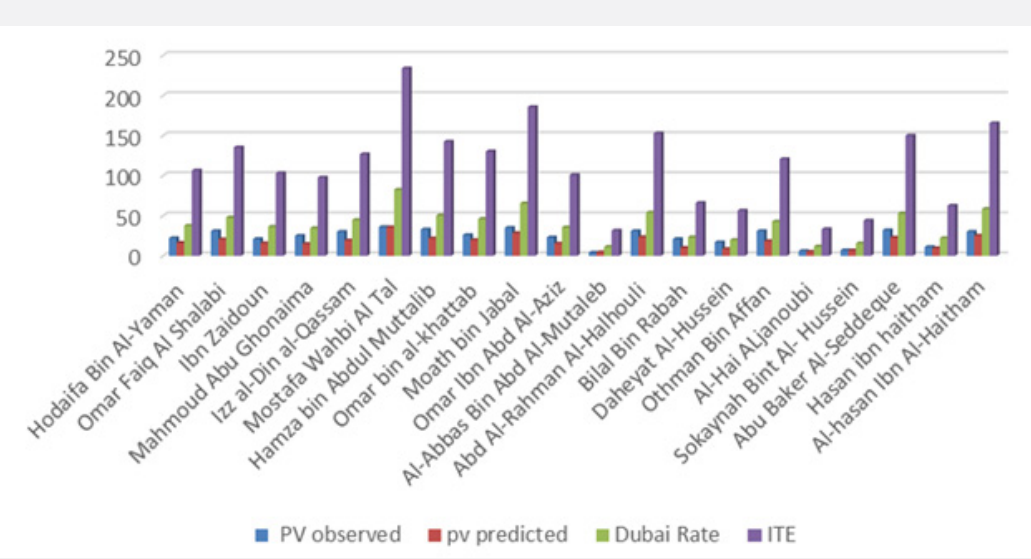

Figure 2: Comparison between observed and predicted parking demand from Developed, ITE and Dubai rates for male elementary public schools.

\section{References}

1. ITE (2010) Parking Generation Manual. Washington, DC, USA, $4^{\text {th }}$ Edition.

2. Dubai Municipality (1998) Trip Generation and Parking Rates Manual. Dubai, UAE, First Edition.

3. (2010) Riyadh Municipality. Riyadh Parking Generation Rates Manual.

4. Al-Masaeid, H, Al-Omari B, Al-Harahsheh A (1999) Vehicle parking demand for different land uses in Jordan. ITE Journal on the Web $\mathrm{p}$ : 79-84.

5. Ghuzlan K, AL-Omari B, Khasawneh M (2016) Parking Demand for Residential Apartment Buildings in Jordan. ITE Journal. 86 (7): 32-36.

6. (2010) ITE at the University of Washington (UW-ITE). Trip Generation and Parking Demand Roosevelt High School, final report. University of Washington, USA p: 1-10.

7. Wong S, Tong C, Lam W, Rayson Y (2000) Fung Development of Parking Demand Models in Hong Kong. Journal of Urban Planning and Development. 126(2): 55-74.

8. (2013) ITE at the Arizona State University (ASU-ITE) Parking Demand and Trip Generation at Elementary Schools. Arizona State University, USA p: $1-28$

9. Department of Statistics (2019) Jordan Population by Municipalities and Gender Amman, Jordan.

10. Alhamdan R (2018) Parking Generation Rates for Schools in Irbid City M. Sc Thesis in Civil Engineering at the Jordan University of Science and Technology Irbid, Jordan.

Your next submission with Juniper Publishers
will reach you the below assets
- Quality Editorial service
- Swift Peer Review
- Reprints availability
- E-prints Service
- Manuscript Podcast for convenient understanding
- Global attainment for your research
- Manuscript accessibility in different formats
( Pdf, E-pub, Full Text, Audio)
- Unceasing customer service
Track the below URL for one-step submission
https://juniperpublishers.com/online-submission.php

